\title{
THE EFFECT OF OWNER/MANAGER'S PERSONAL CHARACTERISTICS ON SME BRAND DEVELOPMENT IN ZIMBABWE
}

\author{
Edinah Mandizwidza-Moyo \\ Limkokwing University of Creative Technology, Faculty of Business \\ \& Globalization, P. Bag 0092, Gaborone, Botswana
}

DOI: 10.46609/IJSSER.2020.v05i01.005 URL: https://doi.org/10.46609/IJSSER.2020.v05i01.005

\begin{abstract}
The purpose of this study is to assess the role of owner/manager's personal characteristics in small to medium enterprise brand development. The role of the owner/manager's personal characteristics in brand development has been overlooked and existing literature has failed to properly conceptualize how brand identity in SMEs is developed. The study utilises a survey research design adopting a quantitative research approach on 500 SMEs operating in three cities in Zimbabwe. Data was collected using a self-administered questionnaire which was administered to the owner/managers of the business utilizing purposive sampling technique. The study excluded SMEs operating in the rural areas of Zimbabwe and only targeted owner/managers; thus, reflecting the supply-side of branding in SME. The findings of the research based on a multiple regression analysis indicate that the owner/manager's inherent characteristics affect the brand identity conceptualizations in SMEs particularly ethnic identity, extraversion and creativity. On the contrary, age, educational level, agreeableness and neuroticism have no bearing on SME brand identity. The study contributes to knowledge generation in terms of the role of owner/manager's personal characteristics on SME brand development as extant literature has significantly overlooked the impact of personal characteristics of the owner/manager in the conceptualization of SME branding development. This study contributes to the existing body of knowledge on the conceptualization of brand development in SMEs; any area which has been overlooked by existing literature.
\end{abstract}

Keywords: Brand Development, Brand Identity, Owner/manager, Personal Characteristics and Small and Medium Enterprise (SME).

\subsection{INTRODUCTION}


International Journal of Social Science and Economic Research

ISSN: $2455-8834$

Volume: 05, Issue: 01 "January 2020"

Research on branding in SMEs has been limited mainly on issues of brand management in SMEs (Abimbola \& Vallaster, 2007; Doyle, 2003; Bresciani \& Eppler, 2010; Gundala et al, 2014; Krake, 2005; Wong \& Merrilees, 2005; Suntivong, 2014). This has resulted in poor and ambiguous conceptualization of SME branding development strategy which has further resulted in an unclear theoretical perspective as to how the brands are formulated in these businesses. The rampant growth of emerging new businesses is continuously putting pressure for businesses to skillfully launch and manage their brands (Abimbola, 2001; Ahonen, 2008; Doyle, 2003). However, this is one area of weakness for most SMEs due to the fact that most owner/managers lack the basic appreciation and knowledge on branding principles, lack the financial capacity to invest in brand development and human resources to build and manage their brands (Berthon, et al, 2008). In most cases, these SMEs do not invest much in brand development as they regard the 'operating name' for their businesses as sufficient brand identities. Effective branding strategies are mainly regarded as a forte of big established organization and a waste of SME resources such as time, capital and human resources (Lukoma \& Nguyen, 2011). Therefore, the objective of this study is:

$>$ To assess the role of owner/manager's personal characteristics in SME brand development.

\subsection{LITERATURE}

\subsection{Overview of Small and Medium Enterprises}

SMEs do not have a universal definition (Stokes \& Wilson, 2017). They are defined differently by different authors and across different countries. However, it is generally agreed that small and medium enterprises encompass owner managed businesses, family businesses and startups (Wilson \& Stoke, 2017). These enterprises are also classified on the basis of measurement such as total number of employees, annual turnover, production levels and size of startup capital (Carson \& Crombie, 1989; Chirisa et al, 2012; Chivasa, 2014; Stoke \& Wilson, 2017). According to the Zimbabwe SME Act (2011) micro, small and medium enterprises (MSMEs) are classified as businesses employing one to seventy five people with a maximum turnover of $\$ 1$ million and a maximum gross asset value of $\$ 500000$.

\subsection{Branding Defined}

The word 'brand' comes from the Old Norse word brand, which means 'to burn' as brands were the means by which the livestock owners historically used to burn their animals to differentiate them from other owners' (de Chernatony \& Dall'Olmo-Riley, 1998; Elliot \& Percy, 2015). A brand is a name, term, sign, symbol or design, or combination of them, intended to identify the goods or services of one seller or group of sellers and is used to differentiate them from those of 


\section{International Journal of Social Science and Economic Research}

competitors (American Marketing Association, 1960). A brand is, therefore, a mixture of attributes, tangible and intangible, symbolized in a trademark which, if managed properly, creates value and influence (Aaker \& McLoughlin, 2010; Berthon et al, 2008). This view has different interpretations. From a consumer perspective it is the promise and delivery of an experience; from a business perspective it is the security of future earnings and from a legal perspective it is a separable piece of intellectual property (Gisip \& Harun, 2013).

In general, branding has been seen as a specialized area of big businesses although this should not be so, as brands represent a valuable intangible asset to all types of organisations (Elliot \& Percy, 2015; Keller, 2013). The concept of branding offers organizations with a differentiation strategy founded on a unique identity that enables effective positioning in the customers' minds and differentiates one producer from another (de Chernatony, 2010) and the ability to resonate with customers (Keller, 2013). Branding is also the inherent self-concept of a company, which is centered on the existing company culture; communicated in appearance, design, communication channels and attitude of all employees (Keller, 2013). Branding supports customer acquisition, retention and it acts as a foundation for building a favorable reputation for the business (Aaker \& McLoughlin, 2010). Branding has taken a center stage in businesses because it is one of the elements that draw the customer closer to the organization and strengthens lasting relationship with them (Elliot \& Percy, 2015).

\subsection{Brand Development in Small to Medium Enterprise}

The creation of a brand requires the establishment of an identity, investment of time and money. In most cases, brand development for SMEs is a haphazard process involving trial and error due to the fact that these SMEs do not have established identities, well designed brand elements, reputation and internal structures still have to be built (Abimbola, 2001; Abimbola \& Vallaster, 2007; Doyle, 2003; Bresciani \& Eppler, 2010; Merrilees, 2007). In addition, due to the lack of effective brand development and brand management, small to medium enterprises fail to tap into the rewards of brand equity (Elliot \& Percy, 2015). Brand equity is the added value a product or brand accrues as a result of past investments in the marketing of the brand (Elliot \& Percy, 2015; Keller, 2013; Osakwe, et al, 2015; Schmidt \& Baumgarth, 2015). It is a bridge between what happened to a brand in the past and what should happen to it in the future. With that in mind, it becomes even more difficult for SMEs to reap the positive rewards emanating from brand equity as they have not even established the brands in the first place.

Therefore, before brand management and reaping from brand equity in SMEs can take place, brand development has to take precedence. For SMEs to develop their brands, fundamental issues of brand identity formulation in relation brand elements have to be clearly articulated. Some scholars (Abimbola \& Vallaster, 2007; Centeno et al, 2013) concur that brand 


\section{International Journal of Social Science and Economic Research}

ISSN: $2455-8834$

Volume: 05, Issue: 01 "January 2020"

development strategies for large organizations might also work for small to medium enterprises. However, Centeno et al, (2013) proposed a five phases of brand development in small to medium enterprises subdivided in to two stages: the starting stage and the development stage. The starting stage of brand development has four phases: (i) brand as a person, (ii) brand as a product and brand differentiation, (iii) brand as a symbol and (iv) brand as an organization. The development stage of brand has only one phase - brand identity and brand growth. However, the development stage (brand identity and brand growth) is the most crucial phase in brand development as all other four phases (starting stage) are based and linked to the issue brand identity. Therefore, brand identity should be the starting point for effective brand development in small to medium enterprises.

\subsection{Brand Identity}

There is significant literature dedicated to brand identity in relation to large organizations (Aaker, 2013; de Chernatony, 2010; Kapferer, 2013; Spence \& Essoussi, 2010). Brand identity is what the organisation wants the brand to stand for in the minds of the customers (Aaker, 2013) and how the brand is to be perceived (Spence \& Essoussi, 2010). Brand identity is the construct of explicit facets of the brand's distinctiveness and value that differentiates it from other brands (Kapferer, 2013), therefore, can be compared to identity of an individual that reflects uniqueness and individuality. Furthermore, it is the distinctive, central ideal of how the brand communicates with its stakeholders (de Chernatony, 2010). From the above definitions, three major issues arise, firstly, brand identity emanates from within the organization. Secondly, the owners of the business play a crucial role in the development of brand identity and lastly, brand identity has to be visionary and long term. This resonates to a large extent with the stages of brand development in the brand resonance model (Keller, 2008); which begin with analyzing issues of establishing an identity - through asking the following questions which are internally focused: (a) who are you? (b) What are you (meaning)? (c) What about you (response)? and lastly, what about you and me (relationship)?

\subsection{Owner/Manager Personal Characteristics}

The influence of the owner/manager characteristics on brand development are of great importance when it comes to SMEs, especially during the formative years. The owner/manager's personal characteristics include inter-alia age, educational levels, motivation, past experience and cultural background (Watson, 2004; Hill, 2002). In SMEs, brand identity development is strongly associated with the innovative personality of the owner/manager (Doyle, 2003). The owner/manager makes most of the decisions pertaining the business and information dissemination is centralized to the owner/manager. By so doing, business strategies for SMEs tend to be arbitrary and informal (Gilmore et al, 2001). The owner/manager's personal 


\section{International Journal of Social Science and Economic Research}

ISSN: $2455-8834$

Volume: 05, Issue: 01 "January 2020"

characteristics have significant bearing on how the brand will be designed, constituted and implemented in the business (Horan et al, 2011; Rode \& Vallaster, 2005). The role of the owner/manager in the SME brand management has been under study in the recent past (Abimbola \& Kocak, 2007; Berthon et al, 2008; Doyle, 2003; Horan et al, 2011; Krake, 2005; Merrilees, 2007; Vidic \& Vadnjal, 2013) which assisted in the literature development and hypothesizing of relationships in this study as following:

$\mathbf{H}_{1}$ : Owner/manager's personal characteristics have a positive and significant effect on SME brand development.

\subsubsection{Age}

The association between the age of the owner/manager and business performance has been researched before (Bolo et al, 2011; Kanuu, et al, 2012). These studies posit that younger owner/managers are associated with high levels of risk taking, innovativeness, higher propensity of novel ideas and experimenting with different business approaches. Younger owner/managers are also associated with high levels of business growth due their ability of taking risks and trying new ideas (Bolo et al, 2011). On the other hand, older owner/managers tend to be more conserve in their business approach, usually make informed decisions based on research and take longer in making decisions (Kanuu et al, 2012). This may also be a result of reduced cognitive capabilities such as learning, reasoning and memory diminishing with age. However, existing literature is lacking in linking the age of the owner/manager and brand development. This current study thus, also seeks to investigate how the age of the owner/manager affects brand development in small to medium enterprises as hypothesized below.

H1a: The owner/manager's age has a significant effect on SME brand development.

\subsubsection{Educational Level}

Education is a key component that molds our people, society and is also fundamental to business management (Becker, 1993). Education is the key source of skills building, knowledge generation, bases of expert power and human development (Unger et al, 2009) Extant literature (Wekesa et al., 2016; Ogega \& Maturi, 2016; Goedhuys \& Sleuwaegen, 2010; Storey, 1994) mainly assess the effect of owner/managers' educational levels on business performance. The results of these studies indicate that there is positive relationship between the educational level of the owner/manager and business performance. However, extant literature has failed to articulate the relationship of education and brand development. This has been necessitated by the fact that existing literature on small and medium enterprise branding is lacking in terms of how brand development is conceptualized thus concentrates mainly on brand management strategies. Therefore, this research hypothesizes the following: 


\section{International Journal of Social Science and Economic Research}

ISSN: $2455-8834$

Volume: 05, Issue: 01 "January 2020"

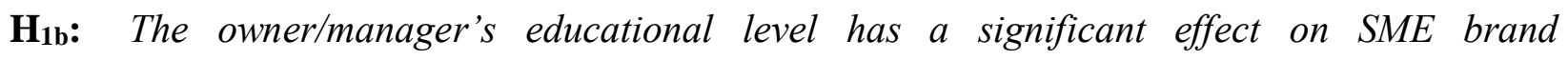
development.

\subsubsection{Ethnic Identity}

Ethnic identity is an important component that assists in defining a person's individualized and collective identity (Phinney, 1990; Phinney \& Ong, 2007; Sirgy, 1982) and it explains who a person is (Erikson, 1959; Eysenck, 1975). Furthermore, it is a person's identification with a segment of a larger society whose members are thought to have a common origin and share segments of a common culture (Yinger, 1976). Ethnic identity is primarily triggered by social and cultural influences surrounding an individual (Phinney, 1990). Social influences based on interaction with others through positive and negative treatment, messages received by an individual overall shape an individual's ethnic identity (Eysenck, 1975). Through this socialization, a person learns what is acceptable, wrong or right and the need to belong to a particular group of people who share the same belief and value system (Eysenck, 1975). In addition, cultural influence is portrayed in an individual's religion, values, family, language, art and educational dynamics also significant shape an person's ethnic identity (Helms, 1994). An individual's ethnic identity will, therefore, manifest itself in the person's day to day activities, behaviour, attitudes and mannerisms. Furthermore, ethnic identity allows a persons to interpret and make sense of the world surrounding him or her and according the person a sense of belonging and pride in whom they are (Helms, 1994; Phinney, 1990). There have been numerous studies on brand identity (Keller, 2013; Urde, et al., 2013) and the interrelationship between brand identity and customer identity and personality (Elliot \& Percy, 2015; Keller, 2013). However, existing SME branding literature has failed to empirical test the interrelationship between the owner/manager's ethnic identity and small to medium enterprise brand development. This relationship is significant in SME brand development as most owner/managers of these businesses base their brands on personal connotations (Doyle, 2003). Therefore, the study hypothesis the following:

H1c: The owner/manager's ethnic Identity has a significant effect on SME brand development.

\subsubsection{Personality Traits}

An individual's personality shapes how a person behaves regardless of the situation and prevailing environment (Aaker, 2013). It is reflected in an individual's attitude, spoken words, behaviour and thought process (Chen \& Chang, 1989). Aliport (1961) postulates personality as the 'real person' and defines personality as the dynamic organization of psycho-physiological systems that create a person's characteristic pattern of behaviour, thoughts and feelings. Furthermore, an individual's personality traits are mainly generated by nature and are general 


\section{International Journal of Social Science and Economic Research}

ISSN: $2455-8834$

Volume: 05, Issue: 01 "January 2020"

stable - enduring over time (Aliport, 1961; Cattell, 1943). However, an individual's personality traits may evolve or even change due to learning and psychological maturity or divergent (Sternberg, 2000). Numerous studies (Aliport, 1961; Cattell, 1943; Eysenck, 1975; McCrae et al, 1986) have contributed to the conceptualization of personality trait theory in an attempt to categorise an individual's personality. Every individual possesses the same set of traits (Sternberg, 2000). An individual's variance emanates from the combination of traits which varies from one person to another; thus forming an individual's set of specific traits (Sternberg, 2000). McCrae et al. (1986) proposed a classification of personality traits into five factors - Big Five Model: Extraversion, Agreeableness, Conscientiousness, Neuroticism and Openness.

Personality traits of the owner/managers have a significant bearing on this study as the study seeks to investigate how the owner/manager's personality trait affect small to medium enterprise brand development and management. The owner/manager's personality tended to be reflected throughout the business (Gundala et al, 2014). Therefore, the conceptualization of owner/manager personality traits assists in the development of the following hypothesized relationships:

H1d: The owner/manager's extraversion personality trait has a significant effect on SME brand development.

$\mathbf{H}_{1 \mathbf{e}}$ : The owner/manager's agreeableness personality trait has a significant effect on SME brand development.

H1: $\quad$ The owner/manager's neuroticism personality traitshas a significant effect on SME brand development.

H.g: The owner/manager's creativity personality trait has a significant effect on SME brand development.

\subsection{RESEARCH METHODOLOGY}

A survey research design was carried out on 500 small and medium enterprise owner/managers based in the three largest cities in Zimbabwe being Harare (250 SMEs), Bulawayo (150 SMEs) and Gweru (100 SMEs). The three cities were selected on the bases of population size, cultural diversity and the level of business activities that are taking place in the three cities. The study utilized purposive sampling techniques which is a non-probability sampling technique that enables a researcher to utilize subjective judgments drawn on academic theory and the experience (Bryman \& Bell, 2017; Malhotra, 2013). Data was collected utilizing a selfadministered questionnaire to the 500 owner/managers in Harare, Bulawayo and Gweru. Of the 


\section{International Journal of Social Science and Economic Research}

ISSN: $2455-8834$

Volume: 05, Issue: 01 "January 2020"

500 questionnaires distributed, $n=376$ (75\%) questionnaires were successfully completed by the respondents and thus were used for data analysis.

\subsection{FINDINGS}

\subsection{Demographic Profile of the Sample}

Table 1 below indicates the demographic profile of the respondents and the characteristics of the SMEs who participated in the research. A large proportion of the respondents were female (64\%) and are either Shona $(53 \%)$ or Ndebele $(31 \%)$. Furthermore, a majority of the respondents are aged below the 40 years (83\%); have a Degree as their highest level of education (46\%) and followed by $26 \%$ respondents having a Diploma level of education. Thus, a majority of the owner/managers of the SMEs in Zimbabwe are young and highly educated. The results presented in Table 1 further demonstrates that a majority of the SMEs are in the retailing sector (38\%), followed by those in the service industry (30\%) and the manufacturing sector with $16 \%$ of the respondents. The majority of the SMEs are registered with local authorities in Zimbabwe (88\%).

Table 1: Profile of the Sample and Descriptive Characteristics $(n=376)$

\begin{tabular}{|l|c|c|}
\hline Variable: Demographic Characteristics & Frequency & Valid Percentage \\
\hline Gender & & 36 \\
\hline Male & 134 & 64 \\
\hline Female & 242 & 31 \\
\hline Cultural Tribe & 107 & 53 \\
\hline Ndebele & 185 & 16 \\
\hline Shona & 56 & \\
\hline Other & & 32 \\
\hline Age & 112 & 51 \\
\hline Less than 25 years & 178 & 13 \\
\hline $26-40$ years & 45 & 4 \\
\hline $41-55$ years & 13 & 1 \\
\hline $56+$ years & & 4 \\
\hline Educational Level & 4 & 9 \\
\hline Zimbabwe Junior Certificate & 40 & 3 \\
\hline O Level & 33 & 26 \\
\hline A Level & 10 & 46 \\
\hline Certificate & 96 & 4 \\
\hline Diploma & 168 & \\
\hline First Degree & 13 & \\
\hline Masters & & \\
\hline Industry & & \\
\hline
\end{tabular}


International Journal of Social Science and Economic Research

ISSN: $2455-8834$

Volume: 05, Issue: 01 "January 2020"

\begin{tabular}{|l|c|c|}
\hline Manufacturing & 55 & 16 \\
\hline Retailing & 133 & 38 \\
\hline Services & 105 & 30 \\
\hline ICT & 24 & 7 \\
\hline Construction & 13 & 4 \\
\hline Other & 19 & 6 \\
\hline Registration with Local Authority & & 88 \\
\hline Yes & 321 & 12 \\
\hline No & 43 & \\
\hline
\end{tabular}

\subsection{Branding Efforts of Small and Medium enterprises}

Table 2 reflects the branding efforts undertaking by the SMEs who participated in the study. The results indicate that family culture (42\%) and individual characteristics $(41 \%)$ were the key factors that influenced their brand identity of their businesses. The majority of the respondents (69\%) stated that Name (48\%) and Name \& Logo (21\%) are the brand elements they are utilizing in their businesses. Brand meaning based on Name had the highest level of respondents who highlighted that their brand is a name (52\%), followed by brand meaning based on Personal Characteristics (26\%), Business Description (17\%) and Ubuntu (6\%). These results, therefore, indicate that the personal characteristics of the owner/managers of SMEs in Zimbabwe have a great bearing on brand development. Most of the SMEs base their brand identities on the name, culture and the different personal characteristics of the owner/managers. In addition, the brand identities of most of these SMES have a cultural connotation that reflects the owner/manager's ethnicity.

Table 2: Branding Efforts of Small and Medium Enterprises $(n=376)$

\begin{tabular}{|l|c|c|}
\hline \multicolumn{1}{|c|}{ Variable } & Frequency & Valid Percentage \\
\hline Brand Influence & & 41 \\
\hline Individual Characteristics & 151 & 42 \\
\hline Family culture & 154 & 6 \\
\hline Customer characteristics & 22 & 1 \\
\hline Competitor brands & 4 & 9 \\
\hline Business environment & 34 & \\
\hline Brand Elements & & 49 \\
\hline Name & 179 & 6 \\
\hline Logo & 21 & 5 \\
\hline Slogan, Design & 17 & 21 \\
\hline Name, Logo & 77 & 6 \\
\hline Name, Design & 22 & \\
\hline
\end{tabular}


International Journal of Social Science and Economic Research

ISSN: $2455-8834$

Volume: 05, Issue: 01 "January 2020"

\begin{tabular}{|l|c|c|}
\hline Name, Slogan & 14 & 4 \\
\hline Name, Logo, Slogan & 11 & 3 \\
\hline Other & 27 & 9 \\
\hline Brand Meaning & 169 & 52 \\
\hline Name & 84 & 26 \\
\hline Personal characteristics & 54 & 17 \\
\hline Business description & 19 & 6 \\
\hline Ubuntu & & \\
\hline
\end{tabular}

\subsection{Validity \& Reliability}

To improve on the internal validity of this study, only owner/managers of SME in Zimbabwe were given the questionnaire to complete. A reliability test using inter item correlations with Cronbach's Alpha was performed on key constructs with the minimum acceptable level of reliability for the study set at $\alpha=60$ (Churchill, 1991; Slater, 1995).

\subsubsection{Brand Development - Brand Identity}

An initial interitem correlation with Cronbach's Alpha test for Brand Identity resulted in a Cronbach's Alpha of .71. However, an analysis of the inter-item correlations indicated that one scale item (Our brand is based on who I am) had a low inter item correlation of -.05 and it also indicated that if the item was to be deleted the $\alpha$ will increase to .76. Based on the importance of this scale item a decision was taken not delete the item but to recode the item. Recoding of the item was subsequently done and a second reliability test was carried out which resulted in a Cronbach's Alpha of .73 as indicated in Table 3 below. This increased reliability level is above the Cronbach's Alpha = .70 (Nunnally, 1978), hence it is acceptable as the construct passes the reliability test.

Table 3: Inter Item Correlations Tests for Brand Development - Brand Identity

\begin{tabular}{|l|c|c|}
\hline \multicolumn{1}{|c|}{ Construct: Brand Identity $(\boldsymbol{\alpha}=. \mathbf{7 3})$} & $\begin{array}{c}\text { Inter Total } \\
\text { Correlation }\end{array}$ & $\begin{array}{c}\text { Cronbach Alpha } \\
\text { if Deleted }\end{array}$ \\
\hline Our brand is difficult to copy. & .67 & .69 \\
\hline Recoded Our brand is based on who I am. & .05 & .76 \\
\hline Our brand represents the culture of our organization. &. .43 & .68 \\
\hline Our brand is an important element in our organization. & .48 & .67 \\
\hline Our brand differentiates us from our competitors. & .56 & .65 \\
\hline Our brand is helpful in making our organization recognizable. & .44 & .65 \\
\hline Our customers recognize our brand easily. & & .68 \\
\hline
\end{tabular}


International Journal of Social Science and Economic Research

ISSN: $2455-8834$

Volume: 05, Issue: 01 "January 2020"

\begin{tabular}{|l|c|c|}
\hline We actively promote our brand all the time. & .45 & .67 \\
\hline $\begin{array}{l}\text { Our office layout, colours, logo and clothing represent our brand } \\
\text { values. }\end{array}$ & .28 & .70 \\
\hline
\end{tabular}

\subsubsection{Ethnic identity}

An initial inter item correlations with Cronbach's Alpha test was performed on the ethnic identity concept, which resulted in a Cronbach's Alpha of $\alpha=.74$; which is above the minimum acceptable level of .70 (Nunnally, 1978). However, further investigation of the inter item correlations indicated that two items (My ethic identity is more important than others and I am active in organizations or social groups that include mostly members of my ethnic group) though had an inter item correlation above .20 the acceptable level of inter item reliability (Streiner \& Norman, 2003); if these two items were to be deleted Cronbach's Alpha of the concept would rise. Therefore, these two scale item were deleted and Cronbach's Alpha rose to .85 as indicated in Table 4.

\section{Table 4: Dimensionality \& Reliability for Ethnic Identity Using Inter Item Correlations with Cronbach's Alpha}

\begin{tabular}{|l|c|c|}
\hline \multicolumn{1}{|c|}{$\begin{array}{c}\text { Concept: Ethnic Identity } \\
\boldsymbol{\alpha}=\mathbf{8 5}\end{array}$} & $\begin{array}{c}\text { Inter Total } \\
\text { Correlation }\end{array}$ & $\begin{array}{c}\text { Cronbach Alpha if } \\
\text { Deleted }\end{array}$ \\
\hline I spend time trying to find out more about my ethnic group. & .53 & .88 \\
\hline I have a strong sense of belonging to my own ethnic group. & .72 & .80 \\
\hline $\begin{array}{l}\text { I understand pretty well what my ethnic group membership } \\
\text { means to me. }\end{array}$ & .80 & .77 \\
\hline I feel a strong attachment towards my own ethnic group. & .76 & .78 \\
\hline
\end{tabular}

\subsubsection{Personality Traits}

Personality traits for this study are a multidimensional concept that was adopted from the Big Five Factor Model proposed by John \& Srivastava (1999). Fifteen scale items were adopted and were divided into five personality traits dimensions: Extraversion, Agreeableness, Neuroticism, Conscientiousness and Openness. An initial inter item correlations with Cronbach's Alpha test was performed on each dimension of Personality Trait. Extraversion resulted in a high Cronbach's Alpha of $\alpha=.92$; thus will be retained for the further analysis. Agreeableness indicated a Cronbach's Alpha of $\alpha=.47$ which was below the acceptable range of .60 (Churchill, 


\section{International Journal of Social Science and Economic Research}

ISSN: $2455-8834$

Volume: 05, Issue: 01 "January 2020"

1991; Slater, 1995). However, further analysis of each scale item's inter item correlations if item deleted indicated that if one item (I see myself as someone who does not find fault with other) was to be deleted Cronbach's Alpha would rise to $\alpha=.62$. Therefore, this scales item was deleted and the Cronbach's Alpha for Agreeableness rose to $\alpha=.62$. In addition, the personality traits sub dimension Neuroticism had an initial Cronbach's Alpha of $\alpha=.68$ which is above the minimum acceptable range of .60 (Slater, 1995). Nonetheless, an analysis of the each item's Cronbach's Alpha if item was deleted indicated that the deletion of one item (I see myself as someone who does not get upset easily) would increase the Cronbach's Alpha level to $\alpha=.71$. This scale item was then deleted resulting in the increase of the Cronbach's Alpha to $\alpha=.71$. However, the remaining dimensions of Personality Traits being Conscientiousness and Neuroticism had low Cronbach's Alphas of $\alpha=.29$ and $\alpha=.42$ respectively.

To assess whether to keep or disregard these sub dimensions of personality traits with very low Cronbach's Alpha levels, further investigation on the personality traits concept was done using Exploratory Factor Analysis (EFA) with Varimax Rotation. The EFA was performed on the 13 items remaining after deletion of two items; which resulted in four components instead of five components being extracted for personality traits. The results of the EFA indicated four items were extracted using the Principal Component Analysis with Eigen values greater than one. The four items have a cumulative percentage loading of $60.81 \%$, which is higher than the minimum acceptable level of 50\% (Hair et al., 2010). The cumulative percentage loading reflects the total percentage that the extracted items contribute towards explaining the concept. The KeiserMeyer-Olkins (KMO) level for personality traits is .71 which above the acceptable minimum level .50 (Hair et al, 2010); while the Bartlett's Test of Sphericity level for this concept is highly significant at .00. Furthermore, in analysing how the scales items loaded together, the results from the EFA with Rotated Component Matrix indicates the follows: the original scales items measuring Extraversion and Neuroticism clearly loaded together into component 1 and component 2 respectively. However, the two scale items measuring Agreeableness (component 2) loaded together with an additional scale from Conscientiousness (I see myself as someone who makes last minute plans). In addition, the three scale items for Openness (component 4) also loaded together with two scale items from Conscientiousness (I see myself as someone who does a thorough job all the time and I see myself as someone who is not deterred by consequences). Therefore, component 4 was renamed Creativity to incorporate the elements of both openness and consciousness.

Cronbach's Alpha test was then performed on the four personality traits dimensions as indicated in Table 5. Extraversion and Neuroticism retained their initial Cronbach's Alpha of $\alpha=.92$ and $\alpha$ $=.71$ respectively. However, the new Cronbach's Alpha for Agreeableness fell from .47 to .09 due to the addition of one scale items from Conscientiousness. Further analysis of the individual 


\section{International Journal of Social Science and Economic Research}

ISSN: $2455-8834$

Volume: 05, Issue: 01 "January 2020"

Cronbach's Alpha if item deleted indicated that the deletion of one item (I see myself as someone who makes last minute plans) would rise the Cronbach's Alpha to $\alpha=.61$. Therefore, this scale item was deleted and new Cronbach's Alpha for Agreeableness rose to $\alpha=.61$. Lastly, the new personality trait labelled Creativity was then tested for reliability using five scale items which resulted in a Cronbach's Alpha of $\alpha=.57$. Thus, both of these dimensions of personality traits (Agreeableness and Creativity) now have acceptable levels of reliability and are adopted for this study. Consequently, for the purpose of this study only four dimensions of personality traits are retained being; Extraversion $(\alpha=.92)$, Agreeableness $(\alpha=.62)$, Neuroticism $(\alpha=.71)$ and Creativity $(\alpha=.57)$ and will be used in further test of hypotheses.

\section{Table 5: Dimensionality \& Reliability for Personality Traits Using Exploratory Factor Analysis and Cronbach's Alpha}

\begin{tabular}{|l|c|c|c|c|}
\hline \multicolumn{1}{|c|}{$\begin{array}{c}\text { Concept: Personality Traits } \\
\text { KMO =.71 } \\
\text { Bartlett's Test of Sphericity =.00 }\end{array}$} & $\begin{array}{c}\text { Factor } \\
\text { Coading }\end{array}$ & $\begin{array}{c}\text { Eigen } \\
\text { values } \\
\text { Greater } \\
\text { Than 1 }\end{array}$ & $\begin{array}{c}\text { Variance } \\
\text { Explained } \\
\text { \% }\end{array}$ & $\begin{array}{c}\text { Cronbach's } \\
\text { Alpha }\end{array}$ \\
\hline Extraversion $=\mathbf{6 0 . 8 1 \%}$ & & 3.12 & 24.03 & $\mathbf{. 9 2}$ \\
\hline I see myself as someone who is assertive. & .93 & & & \\
\hline I see myself as someone who is expressive. & .89 & & & \\
\hline I see myself as someone who generates a lot of enthusiasm. & .93 & & & \\
\hline Agreeableness & & 2.00 & 15.37 & $\mathbf{. 6 2}$ \\
\hline I see myself as someone who is helpful. & .76 & & & \\
\hline I see myself as someone who has a forgiving nature. & 71 & & & \\
\hline Neuroticism & & 1.55 & 11.92 & $\mathbf{. 7 1}$ \\
\hline I see myself as someone who handles stress well. & .86 & & & \\
\hline I see myself as someone who remains calm in tense & .81 & & & \\
\hline Creativity & & 1.24 & 9.51 & $\mathbf{. 5 7}$ \\
\hline I see myself as someone who is inventive & .55 & & & \\
\hline I see myself as someone who is has an active imagination & .58 & & & \\
\hline I see myself as someone who is a deep thinker & .61 & & & \\
\hline $\begin{array}{l}\text { I see myself as someone who is does a thorough job all the } \\
\text { time }\end{array}$ & .65 & & & \\
\hline $\begin{array}{l}\text { I see myself as someone who is is not deterred by } \\
\text { consequences of things }\end{array}$ & .51 & & & \\
\hline
\end{tabular}

\subsection{Hypothesis Testing}

Regression analysis was used to test the hypotheses of the study. It is a statistical procedure that permits a researcher estimate the linear or straight line relationship between two or more variable (Hair et al, 2010). Regression analysis also tests for statistical significance thus testing whether 


\section{International Journal of Social Science and Economic Research}

ISSN: $2455-8834$

Volume: 05, Issue: 01 "January 2020"

the observed linear relationship could have emerged by chance or not (Bryman \& Bell, 2017). Of concern in regression analysis is the $R$ square, the standardised beta, the $t$ value and the level of significance ( $\mathrm{p}$ value).

\section{The Effect of Owner/Manager's Age, Educational Level, Cultural Tribe, Ethnic Identity \& Personality Traits Brand Identity of Small and Medium Enterprises}

Hypotheses testing using linear regression analysis with Enter method was performed between the seven independent variables; being Age, Educational Level, Ethnic Identity, Extraversion, Agreeableness, Neuroticism and Creativity and Brand Identity (dependent variable) as shown in Table 6 which resulted in $\mathrm{R}^{2}=.20$. The $\mathrm{R}^{2}=.20$ reflects that the dependent variable is clearly explained by $20 \%$ of the independent variables which reflects an acceptable level of model fit (Neuman, 2013). In addition individual hypothesis tests are discussed as follows: firstly, the results of the regression analysis performed between Age and Brand Identity indicates that Age is has a negative and insignificant relationship to Brand Identity $(\mathrm{S} \beta=-.06 ; \mathrm{t}=-1.02 ; \mathrm{p}=.31)$. Secondly, the regression analysis between educational level and Brand Identity reveal that the owner/manager's educational level also has a negative and insignificant relationship with Brand identity $(\mathrm{S} \beta=-.08 ; \mathrm{t}=-1.47 ; \mathrm{p}=.14)$. Therefore, the hypotheses $\mathrm{H}_{1 \mathrm{a}}$ and $\mathrm{H}_{1 \mathrm{~b}}$ for the study are not supported. A regression analysis was performed between owner/manager's Ethnic Identity and Brand Identity. The results of the regression analysis indicate that Ethnic Identity is negatively but statistically significant to Brand Identity $(\mathrm{S} \beta=-.11 ; \mathrm{t}=-2.36 ; \mathrm{p}=.02)$ thus the hypothesis $\mathrm{H}_{1 \mathrm{c}}$ is supported for this study. The hypothesis test between owner/manager's personality trait Extraversion and Brand Identity indicates that Extraversion has a positive and highly significant relationship to Brand Identity $(\mathrm{S} \beta=.23 ; \mathrm{t}=4.19 ; \mathrm{p}=.00)$. These results reflect that an increase in the owner/manager's personality trait - Extraversion results in increase of .23 in Brand Identity of the SME while holding the other independent variables constant and this relationship has a high significance level of .00 ; where the $p$ value $\leq .1$ is deemed acceptable (Dahiru, 2008), thus the hypothesis of the study $\left(\mathrm{H}_{1 \mathrm{~d}}\right)$ is supported. Furthermore, the hypothesis test performed between the owner/manager's personality trait Agreeableness and Brand Identity indicated that there is a negative and statistically insignificant relationship between Agreeableness and Brand Identity $(\mathrm{S} \beta=-.03 ; \mathrm{t}=-.50 ; \mathrm{p}=.62)$. Consequently, the alternative hypothesis $\left(\mathrm{H}_{1 \mathrm{e}}\right)$ of the study is not supported. The regression analysis results for personality trait Neuroticism and Brand Identity reflect that Neuroticism has a positive but a statistically insignificant relationship with Brand Identity, holding other factors constant $(\mathrm{S} \beta=.07 ; \mathrm{t}=1.29 ; \mathrm{p}=.20)$. Therefore, the hypothesis $\left(\mathrm{H}_{1 \mathrm{f}}\right)$ of the study is not supported. The results of hypothesis test between the personality trait Creativity and Branding identity indicated that Creativity has a positive and 
statistically significant relationship with Brand Identity in small to medium enterprises $(\mathrm{S} \beta=.28$; $\mathrm{t}=5.03 ; \mathrm{p}=.00)$, therefore, the hypothesis $\left(\mathrm{H}_{1 \mathrm{~g}}\right)$ is supported for the study.

\section{Table 6: Effect of Owner/Manager's Age, Educational Level, Cultural Tribe, Ethnic Identity \& Personality Traits Brand Identity of Small and Medium Enterprises}

\begin{tabular}{|c|c|c|c|}
\hline \multirow[t]{2}{*}{ Independent Variables } & \multicolumn{3}{|c|}{$\begin{array}{c}\text { Dependent Variable: } \\
\text { Brand Identity } \\
\mathbf{R}^{2}=.20\end{array}$} \\
\hline & $\mathbf{S \beta}$ & $t$ & Sig \\
\hline $\mathbf{H}_{1 \mathbf{a}}$ :Age & -.06 & -1.02 & .31 \\
\hline $\mathbf{H}_{\text {1.b: }}$ Education & -.08 & -1.47 & .14 \\
\hline $\mathbf{H}_{1 \mathbf{c}}$ : Ethnic Identity & -.11 & -2.36 & .02 \\
\hline H1d: $_{1}$ Extraversion & .23 & 4.19 & .00 \\
\hline $\mathbf{H}_{1 \mathrm{e}}$ : Agreeableness & -.03 & -.50 & .62 \\
\hline Hif: Neuroticism & .07 & 1.29 & .20 \\
\hline $\mathbf{H}_{1 \mathrm{~g}}$ : Creativity & .28 & 5.03 & .00 \\
\hline
\end{tabular}

\subsection{DISCUSSION}

The findings of the study reveal that the owner/manager's ethnic identity and personality traits Extraversion and Creativity have a significant effect on how brand identity is developed in SMEs in Zimbabwe. The results of the hypothesis test between the owner/manager's Ethnic Identity and Brand Identity revealed that Ethnic Identity is negatively but statistically significant to Brand Identity. These results partly confirm findings from existing literature that states that individualized brand decision making is dependent on the owner/manager experience, dynamism, knowledge, characteristics and intuition of the owner/manager (Krake 2005; Spence \& Essoussi, 2010). This is a part confirmation in that the owner/manager's characteristics and intuition would be implied to be guided by the ethnicity of the owner/manager. Therefore, the owner/manager's ethnic identity has a direct effect on SME brand identity. Furthermore, results of the study indicate that SMEs owner/managers in Zimbabwe have a strong ethnic identity that is based on their culture thus issues of ethnic identity play a fundamental role in shaping their lives and business. This is supported by the results in Table1 which indicate that family culture is one of the key factors that influenced their brands. 


\section{International Journal of Social Science and Economic Research}

ISSN: $2455-8834$

Volume: 05, Issue: 01 "January 2020"

Furthermore, the results of the regression analysis performed between Extraversion and Brand Identity indicates that Extraversion has a positive and highly significant relationship to Brand Identity. Therefore, in cases where the owner/manager is an extrovert, the brand identity of the business is well developed, issues of branding are well articulated and the business tends to have a strong brand identity. However, the results of this study indicates that SME owner/managers in Zimbabwe are not extroverts in nature, These results confirm extant literature (Doyle, 2003; Napoli et al, 2005; Fauziah et al, 2011) which posits that most owner managers are not mavericks in their brand strategy but tend to reflect brand personalities that are honest and reliable associated to the owner/manager.

Thirdly, the results of hypothesis test between the personality trait Creativity and Branding identity indicated that Creativity has a positive and statistically significant relationship with Brand Identity in small to medium enterprises. These results confirmed the findings of exiting literature on small and medium enterprise branding efforts which suggests that brand strategy for these businesses is based on the creativity, experience, characteristics of the owner/managers (Abimbola, 2001; Wong \& Merrilees, 2008; Centeno et al, 2013) and the ability of the owner/managers to adapt quickly to changing business environment (Merrilees, 2007; Centeno et al, 2013; Tavares, 2015). Furthermore, the results of this study could be contributed to the fact that these SME owner/managers in Zimbabwe are not inventive though they have an active imagination that enables them to be creative. This is also necessitated by the business environment in Zimbabwe that does not facilitate for the creation of innovative products but it facilitates for the owner/managers to think 'outside the box' through an active imagination so as to survive and out-compete their competitors. These results confirm findings by Chirisa et al (2012) that states that business owners in Zimbabwe have to be flexible, quickly adapt to changing macro environment and have the active imagination to survive the prevailing turbulent business environment. In addition, the findings of this research reveal that the owner/managers are risk takers, deep thinkers who do a thorough job at all times as the market in Zimbabwe is very volatile and business opportunities come and go at a rapid pace. Moreover, the unstable economic conditions in Zimbabwe requires that owner/managers to take risks at all times as the future is unpredictable.

However, the creation of this new personality trait Creativity diverges from the traditional Big Five Factor model (John \& Srivastava, 1999; Tavares, 2015; Farrukh et al, 2016) as the traditional Big Five Factor model has five personality traits being: extraversion, agreeableness, neuroticism, conscientiousness and openness. In this study, only four personality traits emerged due to the fact that two items of conscientiousness loaded together with openness thus creating a different personality trait (Creativity) for the study. The formulation of this new personality trait Creativity enables for the creation of new knowledge which will assist in the management of 


\section{International Journal of Social Science and Economic Research}

ISSN: $2455-8834$

Volume: 05, Issue: 01 "January 2020"

SMEs and a better understanding of the owner/managers operation in hostile business environments such as Zimbabwe.

On the contrary, the results of the study reveal that the owner/manager's age, educational level, agreeableness trait and neuroticism trait are not significant to SME brand identity development. The findings of the study in relation to significance of age of the owner/manager to brand identity, partly confirms the extant literature that posits that age has no direct bearing on the performance of the business (Storey, 1994; Woldie et at., 2008; Isaga, 2015; Wekesa et al, 2016). The hypothesis test performed between Agreeableness and Brand Identity which indicated that there is a negative and statistically insignificant relationship between Agreeableness and Brand Identity. However, the perception results of the study reveal that owner/managers in Zimbabwe are more agreeable in nature due to the prevailing macro environment in Zimbabwe where people have to be patient, tolerant and generally forgiving in nature so as to able to adapt to the political and economic situation in the country. These results conform previous studies (Goldberg, 1990, Mertzler et al, 2011, Farrukh, Ying \& Monsiri, 2016) which state that people with agreeableness traits tend to be more concerned about the feelings of others, avoid being rude to others and are more inclined to helping others. By so doing, agreeableness people are friends to others, support social structures thus creating good rapport with customers which increases their profitability (Nicholson, 2008). Furthermore, extant literature highlights a negative association between the agreeableness trait and extraversion (Mertzler et al, 2011) due to the fact that agreeable people need to maintain harmony thus find it difficult to come up with new ideas that are diffract from the norm.

In addition, the regression analysis results between Neuroticism and Brand Identity reflect that the personality trait Neuroticism has a positive but statistically insignificant relationship with Brand Identity. This indicates that the personality trait Neuroticism has no effect on Brand Identity. This is supported by the fact that owner/managers in Zimbabwe exhibit positive tendencies of neuroticism as as above half of the respondents do not handle stress well and general remain clam in tense situations. This could be a result of them being deep thinkers who are not deterred by consequences they are likely to face. People with high tendencies of neuroticism are generally emotional stable and have the ability to moderate their emotions thus exhibit high levels of confidence (Farrukh et at, 2016).

\subsection{CONCLUSIONS AND LIMITATIONS}

The aim objective of the study was to assess the role of owner/manager's personal characteristics on brand development in SMEs in Zimbabwe. From the findings of the study, the owner/manager's ethnic identity, personality traits Extraversion and Creativity have a direct effect on how brand development in terms of brand identity is conceptualized in the 


\section{International Journal of Social Science and Economic Research}

ISSN: $2455-8834$

Volume: 05, Issue: 01 "January 2020"

organization. The issues of ethnic identity clearly define who a person is and how they portray themselves. In most cases, the SMEs tend to be an extension of the owner/manager thus the personality, identity of the owner/managers is reflected throughout the business. The concept of brand identity especially in SMEs needs to be well managed as it affects how customers relate and associate with the brand in the long term. Therefore, it is imperative that owner/managers of SMEs should avoid as much as possible to incorporate their personal characteristics in to the brand identity particularly the issues of ethnicity as theses have tribalistic connotation thus segregates customers. Therefore, the study recommends that owner/managers should also avoid developing their brands using personal characteristics such as the family names in brand identity development as branding is about resonating with the target audience and not about the owner/manager. In addition, owner/manager have to be customer focused as they development their brand identity thus they should build brand identities that customers can relate to and avoid brand identity development that is based on the character of the owner/manager.

In addition, the findings of the study contribute to existing knowledge by incorporating the owner/manager's personal characteristics in brand identity development. Existing literature has been lacking in clearly conceptualizing how brand identity in SMEs has been done. The study contributes to existing knowledge by indicating how ethnic identity, extraversion and creativity are key aspects in brand identity of SMEs. Furthermore, the study has brought forth a new personality dimension - Creativity thus re-structured the traditional Big Five Personality Trait Model (Extraversion, Agreeableness, Neuroticism, Conscientiousness and Openness) to four personality traits of Extraversion, Agreeableness, Neuroticism and Creativity. The new personality trait of Creativity emerges due to the prevailing political, social and economic environment in Zimbabwe that requires a re-engineering of business practices and personalities to survive the harsh economic environment.

\section{REFERENCES}

Aaker, D. A. (2013). Strategic Marketing Management. (10 ${ }^{\text {th }}$ Ed.).Wiley \& Son. United Kingdom.

Aaker, D. A., \& Mcloughlin, D. (2010). Strategic Marketing Development: A Global Perspective (9th ed.). John Wiley \& Son Ltd, United Kingdom

Abimbola, T. (2001). Branding as a Competitive Strategy for Demand Management in SMEs. Journal of Research in Marketing \&Entrepreneurship, 3(3), 97-106.

Abimbola, T., \& Kocak, A. (2007). Brand Organisation, Identity and Reputation: A Resource Based Perspective, Qualitative Market Research on SMEs, Journal of International Research, 10(4), 416 - 430. 
International Journal of Social Science and Economic Research

ISSN: 2455-8834

Volume: 05, Issue: 01 "January 2020"

Abimbola, T., \& Vallaster, C. (2007). Brand, organisation, Identity and Reputation in SMEs: An Overview. Journal of International Research, 10(4), 341 - 348.

Ahonen, M. (2008). Branding - does it even exist among SMEs? Paper presented at the 16th Nordic Conference on Small Business Research, Estonia.

Aliport, G. W. (1961). Pattern \& Growth in Personality. New York: Holt, Richardt \& Winston.

American Marketing Association.(1960). Marketing Definition \& Glossary of Marketing Terms. Chicago, AMA.

Becker, G. S. (1993). Human Capital: A theoretical \& empirical analysis with specific reference to education. Chicago. University of Chicago Press.

Berthon, P., Ewing, M. T., \& Napoli, J. (2008). Brand Management in Small to Medium Sized Enterprises. Journal of Small Business Management, 46(1), 27-45.

Bolo, D., Muchemi, A. W., \& Ogutu, M. (2011). Diversity in the Top Management Teams and Effects on Corporate Performance. Prime Journals of Business Administration and Management, 1(3), 82-92.

Bresciani, S., \& Eppler, M. J. (2010). Brand New Ventures? Insights on Start-Ups: Branding Practises. Journal of Product and Brand Management, 19(5), 356 - 366.

Bryman, A., \& Bell, E. (2017). Business Research Methods (4 ${ }^{\text {th }}$ Ed.). Oxford University Press, UK.

Carson, D., \& Cromie, S. (1989). Marketing Planning for Small Enterprises: A model \& empirical evidence. Journal of Marketing Management, 5(1), 356 -366.

Cattell, R. B. (1943). The Description of Personality: Basic Traits Resolved Into Clusters. Journal of Abnormal \& Social Psychology, 58, 69-90.

Centeno, E., Hart, S., \& Dinnie, K. (2013). The Five Phases od SME Brand Building. Journal of Brand Management, 20(6), 445-457.

Chen, Z. G., \& Chang, Y. X. (1989). Psychology of Personality (1 ${ }^{\text {st }}$ Ed.). Taipei, Wa-Nann Books Inc.

Chirisa, I., Dumba, S., \& Makura, T. (2012). Innovative, Adaptive \& Survivalist Strategies by Small Business Enterprises in Zimbabwe (1990-2009): Implications for Policy \& 
International Journal of Social Science and Economic Research

ISSN: 2455-8834

Volume: 05, Issue: 01 "January 2020"

Planning. International Journal of Academic Research in Business \& Social Sciences, 2(5), 114-132.

Chivasa, S. (2014). Entrepreneurship Culture among SMEs in Zimbabwe: A Case Study of Bulawayo SMEs. Journal of Economics, Commerce \& Management, 2(9), 1-7.

Churchill, G.A. (1991). Market Research: Methodological Foundations (5 ${ }^{\text {th }}$ Ed.).. The Dryden Press. USA.

de Chernatony, L. D. (2010). From Brand Vision to Evolution (3rd ed.). UK: ButterworthHeinemann.

de Chernatony, L. D., \& Dall'Olmo-Riley, F. (1998). Brand Management through Narrowing the Gap Between Brand Identity and Brand Reputation. Journal of Marketing Management, 15(3), 159 - 179.

Doyle, E. (2003). Study of Entrepreneurial Brand Building in the Manufacturing Sector in the UK. The Journal of Product \& Brand Management, 12(3), 79-93.

Elliot, R. R., \& Percy, L. (2015). Strategic Brand Management (3nd ed.). United Kingdom: Oxford University.

Erikson, E. (1959). Identity and the Life Cycle. New York: Norton Publishers.

Eysenck, H. J. (1975). The Inequality of Man. California: EDITS Publishers.

Farrukh, M., Monsori. S., \& Ying, C. W. (2016). Intrapersonal Behavior: An Investigation of Personality Traits. Management \& Marketing Challenges for Knowledge Society, 11(4), $597-609$.

Fauziah, A., Rohaizar, B., Farzana, Q., \& Mohamad, N. M. M. (2011). Branding Leadership in Malaysia SMEs. Journal of Social \& Behavioural Science, 130, 54 -58.

Gilmore, A., Carson, D., \& Grant, K. (2001). SME Marketing in Practice. Journal of Marketing Intelligence and Planning, 19(1), 6 - 11.

Gisip, I. A., \& Harun, A. (2013). Antecedents and Outcomes of Brand Management from Perspective of Resource Based View (RBV). Theory Mediterranean Journal of Social Science, 4(10), 432 - 441.

Goedhuys, M., \& Sleuwaegen, L. (2010). High Growth Entrepreneurial Firms in Africa: A quantile regression approach. Small Business Economics. 34, 31-51. 
International Journal of Social Science and Economic Research

ISSN: 2455-8834

Volume: 05, Issue: 01 "January 2020"

Goldberg, L.R. (1990). An Alternative Description of Personality: The Big Five Factor Structure. Journal of Personality \& Social Psychology, 59(6), 1216 -1226.

Gundala, R. R., Khawaja, H., \& Jack, A. L. (2014). Brand Management in Small \& Medium Enterprises: Evidence from Dubai, UAE. Global Journal of Business Research, 8(1), 2738.

Hair. J.F., Black. W. C., Babin. B. J.,\& Anderson. R. E., (2010). Multivariate Data Analysis: A global perspective, Vectors ( $7^{\text {th }}$ Ed.). Pearson Prentice Hall. Upper Saddle River, New Jersey.

Helms, J. E. (1994). The Conceptualization of Ethnic Identity and Other Racial Constructs in E. J. Thicket; R. J. Watts \& D. Birman; Human Diversity a Perspective on People in Context. San Francisco: Jossey-Bass.

Hill, R. (2002), What Sample Size is Enough in Internet Survey Research? Interpersonal Computing \& Technology. Electronic Journal of the $21^{\text {st }}$ Century, 6(1), $3-4$.

Hinton, P. R., Brownlow, C., McMurray, L., \& Cozen, B. (2004). SPSS Explained. Routledge Inc. East Sussex, England.

Horan, N., O'Dwyer, M., \& Tiernan, S. (2011). Exploring Management Perspective of Banding in Service SME. Journal of Service Marketing, 25(2), 114-121.

Isaga, N. (2015). Owner-Manager's Demographic Characteristics \& the Growth of Tanzia SMEs. International Journal of Business \& Management, 10(5), 168-176.

John, O. P., \& Srivastava, S. (1990). The Big Five Trait Taxonomy: History, Movement \& Theoretical Perspective. Handbook of Personality, New York, Guilford.

Kanuu, D., Murgor, P., Ongeti, W., Letting, N., \&Aosa, E. (2012). Upper Echelons Theory and Research: A review of theory and empirical literature. Prime Journals of Business Administration and Management, 1(1), 43-45.

Kapferer. J. N. (2013). The New Strategic Brand Management: Advanced Insights \& Strategic Thinking $\left(5^{\text {th }}\right.$ Ed.). Kogan Pages. USA.

Keller, K. L. (2008). Strategic Brand Management (3rd ed.). USA: Upper Saddle Publishers.

Keller, K. L. (2013). Strategic Brand Management (5thed.). USA: Pearson Publishers. 
International Journal of Social Science and Economic Research

ISSN: 2455-8834

Volume: 05, Issue: 01 "January 2020"

Krake, F. (2005). Successful Brand Management in SMEs: A New Theory \& Practical Hints. Journal of Product \& Brand Management, 4(4), 228-238.

Lukoma, V., \& Nguyen, T. K. (2011). Brand Recognition for Long Term Business Growth in Developing Countries. Gotland University Press, 1-3.

Malhotra. N. K. (2013). Review of Market research (10 $10^{\text {th }}$ Ed.). Emerald Group Publishing. UK.

McCrae, R. R., Costa, P. T., \& Busch, C. M. (1986).Evaluating Comprehensiveness in Personality Systems: The California Q-set \& the Five Factor Model. Journal of Personality, 54(2), 430-446.

Merltzer, H., Bebbington, P., Brugh, T., Jenkins, R., McManus, S., \& Dennis, M. S. (2011). Personal Debt \& Suicidal Ideation. Journal of Psychological Medicine. 41, 771-778.

Merrilees, B. (2007). A Theory of Brand-Led SME New Venture Development: Qualitative Market Research. International Journal, 10(4), 403 - 415.

Neuman, W. L. (2013). Social Research Methods: Qualitative \& Quantitative Approaches (New International Ed.). Pearson Education Limited, UK.

Nicholson, N. (2008). Evolution of Psychology \& Family Business: A new synthesis for theory, research \& Practice. Journal of Family Business Review, 21(1), 103 -120.

Nicholson, N., Soane, E., Fenton-O'Creevy, M., \& William, P. (2005). Personality \& DomainSpecific Risk Taking. Journal of Risk Research, 8(2), $157-176$.

Nunnally, J. C. (1978). Psychometric Theory ( $2^{\text {nd }}$ Ed.). New York: McGraw-Hill.

Osakwe, C. N., Chovancova, M., \& Ogbonna, B. U. (2015). Linking SMEs Profitability to Brand Orientation and Market - Sensing Capability: Service Sector Evidence Periodical Polytechnic Social and Management Sciences, 24 (1), $34-40$.

Phinney, J. S. (1990). Ethnic Identity in Adolescents and Adults: Review of the Research. Psychological Bulletin, 108, 499-514.

Phinney, J. S., \& Ong, A. D. (2007). Conceptualization \& Measurement of Ethnic Identity: Current Status \& Future Directions. Journal of Counselling Psychology, 54(3), 271-281.

Rode, V., \& Vallaster, C. (2005). Corporate Branding for Start-Up: The Crucial Role of the Entrepreneurs. Corporate Reputation Review, 8, 121-135. 
International Journal of Social Science and Economic Research

ISSN: 2455-8834

Volume: 05, Issue: 01 "January 2020"

Schmidt, H. J., \& Baumgarth, C. (2015). Brand Orientation: A Case Study Approach Within the Context of Social Entrepreneurial Business. Journal of Social Behavioural Science, 175(1), $24-31$

Sirgy, M. J. (1982). Self-Concept in Consumer Behaviour: A Critical Review. Journal of Consumer Research, 9(3), 287-300.

Slater, S. F. (1995). Issues in Conducting Marketing Strategy Research. Journal of Strategic Marketing, 3 (4), 257-270.

Spence, M., \& Essoussi, L. H. (2010). Brand Building and Management: An Exploratory Study. European Journal of Marketing, 44(7/8), 1037-1054.

Steiner, L. (2003). Roots of Identity in Real Estate Industry. Journal of Corporate Review, 6(2), $178-196$

Sternberg, R. J. (2000). Pathway to Psychology (2nd Edition ed.). New York: Thomson Learning Inc.

Stoke .D., \& Wilson. N. (2017).Small Business Management \& Entrepreneurship, $7^{\text {th }}$ Edition. Cengage Press, USA.

Storey, D. J. (1994). Understanding the Small Business Sector. London. Routledge.

Streiner, D. L., \& Norman, G. R. (2003). Health Measurement Scales: A practical guide to their development. Oxford. University Press Oxford.

Suntivong, D. (2014). Make or break it in SMEs Brand Building, and Empirical Study of the Impact of Brand Development on the Performance of Thai SMEs. Journal of Business \& Management, 16(4), 19-28.

Tavares, V. M. (2015). Brand Management in SMEs: Conceptualization of Difference \& Research Agenda: European Journal of Applied Business Management, 1 (1), 128 - 153.

Unger, J. M., Raunch, A., Frese, M., \& Rosenbusch, N. (2009). Human Capital \& Entrepreneurial Success: A meta-analytical review. Journal of Business Venturing. 26(3), $341-358$.

Urde, M., Baumgarth, C., \& Merrilees, B. (2013). Brand Orientation \& Market Orientation: From Alternatives to Synergy. Journal of Business Research, 66 (1), 13-20. 
International Journal of Social Science and Economic Research

ISSN: 2455-8834

Volume: 05, Issue: 01 "January 2020"

Vidic, F., \& Vadnjal, J. (2013). The Role of Branding in SMEs: Different Perspective on the Market. Business Review, 12(1), 79-88.

Watson, D. (2004). Stability Versus Change, Dependability Versus Error: Issues in assessment of personality over time. Journal of Research in Personality, 38, 319 - 350.

Wekesa, L., Maalu, J. K., Gathungu, J., \& Wainaina, G. (2016). Effect of Entrepreneur Characteristics on Performance of Non Timber Forest Products SMEs in Kenya. DBA Africa Review. 6(3), 16-26.

Woldie, A., Leighton, P., \& Adesua, A. (2008).Factors Influencing SMEs: An exploratory study of owner/manager \& Firm Characteristics. Journal of Banks \& Bank System, 3(3).

Wong, H. Y., \& Merrilees, B. (2005). A Brand Orientation typology for SMEs: A Case Research Approach. Journal of Product and Brand Management, 14(3), 155 - 162.

Wong, H. Y., \& Merrilees, B. (2008).The Performance Benefits of Being a Brand. Journal of Product \& Brand Management, 17(6), 372-383.

Yinger, J. M. (1976). Ethnicity in Complex Societies in L.A. Coser \& O. N. Larsen (eds), The Use of Controversy in Sociology. New York: Free Press.

Zimbabwe SME Act. (2011). Chapter 24:12: MSME Advisory Council. Harare, Zimbabwe. 